\title{
ANNUAL FORAGE CROPS FOR THE SOUTHERN INTERIOR OF BRITISH COLUMBIA
}

PUBLICATION 1265 REVISED 1976

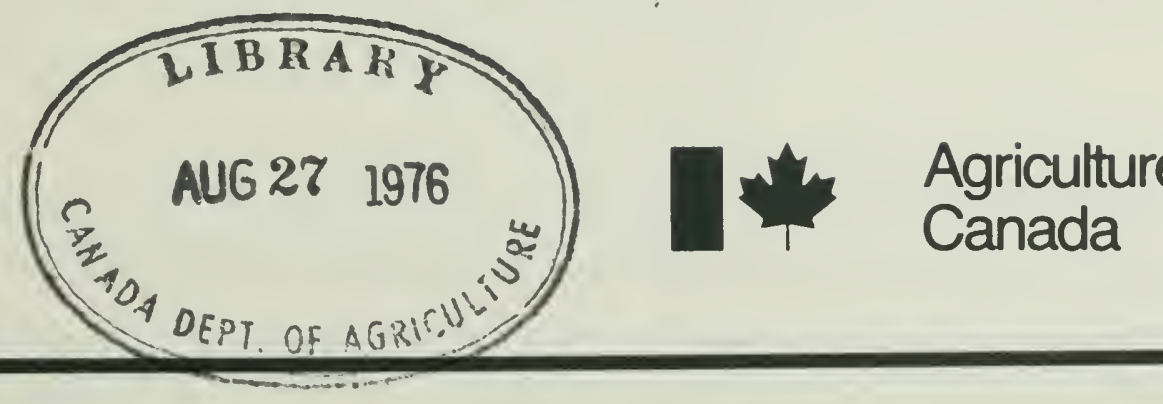

636.4
$C_{212}$
$P-1265$
1976

$c<(n e)$ 
Copies of this publication may be obtained from

INFORMATION DIVISION

CANADA DEPARTMENT OF AGRICULTURE

OTTAWA

K1A OC7

๑ MINISTER OF SUPPLY AND SERVICES CANADA 1976

Printed 1967

Revised 1976

$6 M-6: 76$

\section{RECOMMENDATIONS}

- Use annual forage crops mainly for emergency pasture or hay.

- Seed oats, barley, wheat, or rye at the same rate as a grain crop.

- Seed corn to obtain at least 65000 plants per hectare $(26,000$ plants per acre) on irrigated land. Various row-width/seed-spacing plans are satisfactory but must be matched with seeding and harvesting equipment.

- Practice good management: prepare the seedbed, apply fertilizers, irrigate if required, and control weeds. 


\title{
ANNUAL FORAGE CROPS \\ FOR THE \\ SOUTHERN INTERIOR \\ OF BRITISH COLUMBIA
}

\author{
W.A. Hubbard and D.E. Waldern \\ Research Station, Kamloops, British Columbia
}

Annual forage crops can be used to provide additional or supplementary feed when pastures and hayland have been winter-killed, new seedings of perennial crops have not become established, or livestock numbers have increased.

Several annual crops can be used to provide supplementary pasture in summer or late fall or they can be cut and stored as hay or silage for winter feed. The following crops have been grown successfully in the southern interior of British Columbia: corn (Zea mays L.); cereal and cereal-legume mixtures that include spring oats (Avena sativa L.), fall and spring wheat (Triticum aestivum L.), fall rye (Secale cereale L.), and peas (Pisum arvense L.); Sudan grass and sweet Sudan (Sorghum sudanense (Piper) Stapf); pearl millet (Pennisetum typhoides (Burm. fil) Stapf \& C.E. Hubbard); sorghum and hybrid sorghum (Sorghum bicolor (L.) Moench); marrowstem kale (Brassica oeracea L. var. acephale DC.); and fodder rape (Brassica napus L.).

\section{CORN}

The first choice for an annual forage crop is corn. Its palatability as greenfeed or silage is excellent and its nutritive value exceeds that of other annual crops. Because herbicides have greatly reduced the need for cultivation, corn is easy to grow. In the southern interior of British Columbia, corn outyields all annual forage crops and produces one and one-half times as much dry matter as three cuts of alfalfa.

Green chop corn yields 35-55 t/ha (15-25 tons/ac) and can be fed to dairy or beef cattle from August until the first hard fall frost. Beef cattle, fed corn silage in place of some of the hay in winter rations, often eat more total dry matter and gain better. When hay is scarce, silage can replace all or part of the hay as winter feed. Using the normal silage-to-hay ratio, 3 to $3.5: 1$, you can estimate that a hectare producing 45-65 tonnes of corn silage containing 25\% dry matter can replace 10-20 tonnes of hay. (Similarly, an acre producing 20-30 tons of corn silage can replace $5-10$ tons of hay.)

Corn silage is deficient in one major nutrient: protein. When feeding a ration composed largely of corn silage, you must provide additional protein from alfalfa hay or some commercial supplement. Urea is an economical source of supplemental protein. Adding $5 \mathrm{~kg}$ of feed grade urea per tonne ( $10 \mathrm{lb}$ urea per ton) of wet 
forage corn at ensiling time will increase the crude protein content of the stored forage by $4-5$ percentage units on a dry matter basis. Thus, crude protein will be increased from approximately $9 \%$ to $13.5 \%$. Forage corn can be stored in stacks or many types of temporary silos. In these structures, it must be firmly packed and sealed with plastic to avoid heavy spoilage.

\section{Hybrid corn varieties}

To produce corn silage successfully, you must select a hybrid suited to your area. Each year, the British Columbia Corn Committee publishes a list of recommended hybrid varieties matched to the heat units available in the different corn-growing areas of the province. You can obtain this information from the office of the local District Agriculturist, British Columbia Department of Agriculture.

The total heat units produced in a region during the normal growing season limit the success of corn production. Daily heat units are determined on the basis of temperatures above $10^{\circ} \mathrm{C}\left(50^{\circ} \mathrm{F}\right)$ during the day and $5^{\circ} \mathrm{C}\left(40^{\circ} \mathrm{F}\right)$ at night. The total heat units during the growing season are calculated from planting date in the spring at a mean temperature of $13^{\circ} \mathrm{C}\left(55^{\circ} \mathrm{F}\right)$ until the average date of the first killing frost in the fall, $-2^{\circ} \mathrm{C}\left(28^{\circ} \mathrm{F}\right)$ or lower. Table 1 shows examples of the wide variation in total corn heat units produced in different locations in British Columbia.

TABLE 1. TOTAL CORN HEAT UNITS FOR VARIOUS LOCATIONS IN BRITISH COLUMBIA

\begin{tabular}{|c|c|c|c|}
\hline \multirow[b]{2}{*}{ Location } & \multicolumn{2}{|c|}{ Corn heat units ${ }^{*}$} & \multirow{2}{*}{$\begin{array}{l}\text { Average date of } \\
\text { first killing fall } \\
\text { frost, }-2^{\circ} \mathrm{C}\left(28^{\circ} \mathrm{F}\right) \\
\text { or lower }\end{array}$} \\
\hline & $\begin{array}{l}\text { based } \\
\text { on }{ }^{\circ} \mathrm{C}\end{array}$ & $\begin{array}{l}\text { based } \\
\text { on }{ }^{\circ} \mathrm{F}\end{array}$ & \\
\hline Lytton & 1891 & 3408 & Sept. 30 \\
\hline Keremeos & 1832 & 3300 & Sept. 30 \\
\hline Summerland & 1725 & 3108 & Oct. 3 \\
\hline Kamloops & 1708 & 3077 & Sept. 15 \\
\hline Oliver & 1615 & 2910 & Sept. 15 \\
\hline Agassiz & 1554 & 2800 & Sept. 15 \\
\hline Vernon & 1471 & 2651 & Sept. 15 \\
\hline Abbotsford & 1449 & 2610 & Sept. 30 \\
\hline Penticton & 1443 & 2600 & Sept. 30 \\
\hline Kelowna & 1414 & 2547 & Sept. 23 \\
\hline Salmon Arm & 1388 & 2500 & Sept. 15 \\
\hline Merritt & 1054 & 1900 & Sept. 30 \\
\hline Princeton & $<832$ & $<1500$ & Sept. 10 \\
\hline
\end{tabular}

*Determined by Brown's method (D. M. Brown. A "heat unit" system for corn hybrid recommendations. Paper prepared for 5th National Conference on Agricultural Meteorology, Lakeland, Fla., April 4-5, 1963). 


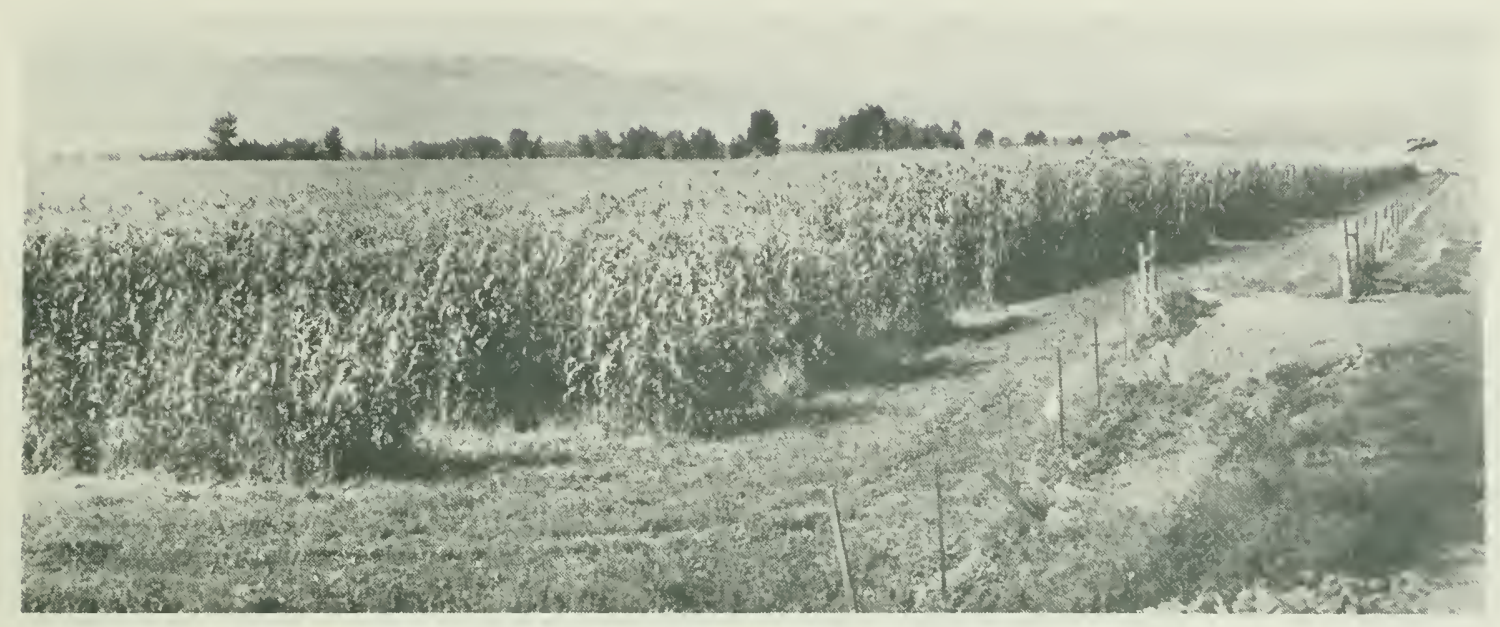

A field of forage corn that yielded about 56 tonnes of silage per hectare 125 tons of silage per acre).

Optimum temperature for corn growth is approximately $30^{\circ} \mathrm{C}\left(85^{\circ} \mathrm{F}\right)$. Higher temperatures tend to slow growth.

Hybrids that use the full growing season put more energy or total digestible nutrients (TDN) into the silo. Late maturing hybrids give the best yield in areas with a high number of heat units. (Earlier maturing hybrids should be used in these areas if seeding is delayed because of cold or wet weather.) In lower heat unit areas, only medium or early hybrids should be used because late hybrids will produce a forage high in moisture and low in energy.

\section{Seedbed preparation and fertilization}

In areas suitable for corn production, 45-65 t/ha (20-30 tons/ac) is a realistic goal for silage production if good techniques for growing corn are followed.

Prepare a fine, firm seedbed. Have a soil test done to determine what fertilizer is needed. (Send soil samples to the British Columbia Department of Agriculture, Soil Testing Laboratory, Court House, Kelowna, B.C.)

Phosphorus, if required, should be banded in with the corn planter. For maximum yield, fertilize with nitrogen at $170 \mathrm{~kg} / \mathrm{ha}(150 \mathrm{lb} / \mathrm{ac})$ in two applications, one-third broadcast with a fertilizer spreader just prior to or after seeding, and two-thirds banded on each side of the row when the corn is $25-40 \mathrm{~cm}(10-16 \mathrm{in}$.) high. Although large amounts of potassium are taken out of the soil by a corn silage crop, few soils in the area need added potassium.

\section{Seeding}

Plant heavily and early, and place the seeds evenly in rows. Tests at the Research Station, Kamloops (Table 2), show that early planting gives maximum yields of 
TABLE 2. EFFECT OF PLANTING DATE ON YIELDS OF CORN SILAGE FROM PIONEER 383 SEEDED AT 64240 PLANTS/HA $(26,000$ PLANTS/AC) (RESEARCH STATION, KAMLOOPS, 1969)

\begin{tabular}{lccc}
\hline & $\begin{array}{c}\text { Whole plant } \\
\text { Planting } \\
\text { date }\end{array}$ & \multicolumn{2}{c}{ Dry matter $^{*}$} \\
\cline { 3 - 4 } & harvest (\%) & t/ha & tons/ac \\
\hline April 1 & 30.3 & 25.1 & 11.1 \\
April 15 & 30.9 & 24.4 & 10.8 \\
April 30 & 31.9 & 26.9 & 11.9 \\
May 15 & 24.5 & 20.6 & 9.2 \\
May 30 & 18.0 & 13.0 & 5.8 \\
June 15 & 16.1 & 11.2 & 4.9 \\
\hline
\end{tabular}

*All seedings were harvested on the same date.

high-energy silage. Early planting gives higher grain yields, which contribute to high-energy silage. Because early planting may result in a 10\% loss of seed, compensate by planting at a slightly heavier rate.

The optimum plant population of corn is between 60000 and 70000 plants per hectare $(24,000$ and 28,000 plants per acre). Table 3 shows the seed spacing that produces the desired plant population.

Select a spacing plan suited to your seeding and harvesting equipment. Use a corn planter if available; otherwise, use a grain drill and block the runs not in use.

Research is being conducted on narrow spacing between rows with plants wider apart within the row to give a better leaf canopy and more space for the roots of individual plants. In this system, rows can be 51-56 cm (20-22 in.) apart if suitable machinery is available for harvesting; the plant population will remain about the same.

Treated seed resists the effects of cold, wet soil better than untreated seed. Most seed companies sell seed that has been treated with a fungicide. If the seed you buy is untreated, use one of the fungicides recommended in the publication Field Crop Disease, Insect, Weed and Rodent Control Recommendations, British Columbia Department of Agriculture. Be sure to follow carefully the directions on the container.

\section{Weed control}

You must control weeds because corn does not compete with actively growing weeds. Use one of the many preemergence or postemergence herbicides recommended in the latest B.C. publication, Field Crop Disease, Insect, Weed and Rodent Control Recommendations, available from your District Agriculturist. Chemical control can be supplemented by the use of a cultivator or rotary hoe. 

CORN PLANT POPULATIONS

\begin{tabular}{|c|c|c|c|c|c|c|c|c|c|}
\hline \multirow{2}{*}{$\begin{array}{l}\text { Seeds } \\
\text { per } \\
\text { acre }\end{array}$} & \multicolumn{8}{|c|}{ Row spacing, inches } & \multirow{2}{*}{$\begin{array}{c}\text { Final } \\
\text { population } \\
\text { allowing } 10 \% \\
\text { stand loss }\end{array}$} \\
\hline & 20 & 24 & 28 & 30 & 32 & 36 & 38 & 40 & \\
\hline \multicolumn{10}{|c|}{$-{ }_{-}-$space between each kernel, inches $-\ldots$} \\
\hline 14,000 & 22 & 19 & 16 & 15 & 14 & 12 & 12 & 11 & 12,600 \\
\hline 15,000 & 21 & 17 & 15 & 14 & 13 & 12 & 11 & 10 & 13,500 \\
\hline 16,000 & 20 & 16 & 14 & 13 & 12 & 11 & 10 & 10 & 14,400 \\
\hline 17,000 & 18 & 15 & 13 & 12 & 12 & 10 & 10 & 9 & 15,300 \\
\hline 18,000 & 17 & 15 & 12 & 12 & 11 & 10 & 9 & 9 & 16,200 \\
\hline 19,000 & 16 & 14 & 12 & 11 & 10 & 9 & 9 & 8 & 17,100 \\
\hline 20,000 & 16 & 13 & 11 & 10 & 10 & 9 & 8 & 8 & 18,000 \\
\hline 22,000 & 14 & 12 & 10 & 10 & 9 & 8 & 8 & 7 & 19,800 \\
\hline 24,000 & 13 & 11 & 9 & 9 & 8 & 7 & 7 & 6 & 21,600 \\
\hline 26,000 & 12 & 10 & 9 & 8 & 8 & 7 & 6 & 6 & 23,500 \\
\hline 28,000 & 11 & 9 & 8 & 8 & 7 & 6 & 6 & 6 & 25,200 \\
\hline 30,000 & 10 & 9 & 8 & 7 & 6 & 6 & 6 & 5 & 27,000 \\
\hline 32,000 & 10 & 8 & 7 & 7 & 6 & 5 & 5 & 5 & 28,800 \\
\hline
\end{tabular}

NOTE: To calculate the seeds per hectare, multiply the seeds per acre by 2.5 ; to calculate the centimetres between rows and kernels, multiply the inches by 2.5 .

Some apparent failures of chemical weed control are due to extremely dry or cold soil conditions at the time of application. In the dry interior of the province, residual effects of some chemicals may remain in the soil for 1 or 2 years and cause injury to susceptible crops such as alfalfa and oats if they are seeded the year after corn. Thus, care should be taken in selection of the proper herbicide if alfalfa is to be seeded after corn.

\section{Irrigation}

In the interior of British Columbia, most corn is grown on irrigated land. When should you irrigate? In general, irrigate before planting. Do not irrigate newly emerged plants because irrigation packs the soil and reduces soil temperature. Corn also needs moisture at the critical stage of growth when the tassels and silk are forming. Irrigation in the late fall fills the soil with moisture and aids the next year's crop.

Problems have arisen when sprinklers have been used to irrigate corn. Tests at the Research Station show that if two rows are left out every $18 \mathrm{~m}$ in a cornfield spaced in 76-cm rows (every $60 \mathrm{ft}$ in a field with 30-in. rows), normal risers on sprinkler pipe supply adequate water. Tall risers tend to vibrate and break off, and if tripod supports are used, it is hard to move the pipe through tall corn. 
Because of the inherent difficulty of moving pipe, interest is growing in towline moving and "rain-guns." These large, rain-gun sprinklers will irrigate $0.2-1.2$ ha $(1 / 2-3 \mathrm{ac})$ at a setting.

In most corn-growing areas, about $3500 \mathrm{~m}^{3}(21 / 2-3 \mathrm{ac} \mathrm{ft})$ of irrigation water are needed for maximum production.

You may need to cultivate in the early stages after planting to break any surface crusting and to aerate the soil.

\section{Harvesting and storage}

Knowing when to harvest is the key to growing profitable silage. Early harvesting is a mistake; well-developed ears on late harvested corn will result in silage with a higher percentage of dry matter, and less plant dry matter will be lost from the silo through seepage. For maximum yield in terms of dry matter, harvest between the hard dent and the glaze stages. Although ears lose moisture rapidly as they mature, even after a frost the stalk contains at least $70 \%$ moisture. Most plant material holds up to $70 \%$ moisture without evidence of seepage at normal silo pressure. As a rule of thumb, for maximum yield, cut corn 50 to 55 days after $75 \%$ of the corn plants have "silked."

You need corn harvesting machinery to produce good silage. You can set the machine to cut the material into $6-19 \mathrm{~mm}(1 / 4-3 / 4 \mathrm{in}$.) pieces. Fine chopping, 6-13 $\mathrm{mm}(1 / 4-1 / 2 \mathrm{in.})$, reduces spoilage through improved packing and air exclusion. (When corn silage is the major forage fed to dairy cattle, chop it into $16-19 \mathrm{~mm}(5 / 8-3 / 4 \mathrm{in}$.$) pieces to avoid any depression in milk fat test.)$

Make the silo as airtight as possible. Fill quickly and pack firmly. After filling a pit or trench, continue packing for at least 2 weeks.

In British Columbia, corn left in the field to obtain maximum maturity runs some risk of frost. Frost-damaged corn produces a silage of lower quality than corn that has reached full dent stage. Harvest heavily frosted corn at once. Leave lightly frosted corn to continue to mature slowly if temperatures are adequate.

You seldom need to add water to forage corn when ensiling unless it is extremely dry; if there is more than $40 \%$ dry matter, add water to improve packing, especially when the material is stored in a bunker or horizontal silo.

\section{Feeding}

Corn silage is a good feed for all classes of cattle. Work at the Research Station, Kamloops, with $215 \mathrm{~kg}(480 \mathrm{lb})$ Hereford calves has shown that a hectare of good corn silage can produce $1600-1700 \mathrm{~kg}$ of beef (or an acre of silage, 1400-1500 lb of beef). The only supplements the cattle received were vitamin $A$, salt, and bone meal. The dry matter consumption of these weaned calves was influenced by the 
moisture content of the silage fed. Maximum dry matter consumption was obtained only when the silage contained 30-35\% dry matter.

Heavier cattle can be finished on a full feed of corn silage, plus limited amounts of grain or concentrates $(2-3 \mathrm{~kg}$ or $4.5-6.5 \mathrm{lb})$. A full feed of grain, along with limited corn silage $(4.5-5.5 \mathrm{~kg}$ or $10-12 \mathrm{lb})$ will produce maximum gains. Animals fed corn silage appear to have greater appetites, stay on feed better, and have fewer digestive troubles than those fed other types of roughage.

The cost of growing corn was estimated at $\$ 435 /$ ha $(\$ 174 / \mathrm{ac})$ in 1973 . Research is currently under way at Kamloops to establish the cost of producing corn under new systems of irrigation and management.

\section{OATS, BARLEY, RYE, AND PEAS}

Oats are superior to other small grains for hay and pasture. Harvest them between the milk and soft dough stages for best quality hay and silage. (When cut at the soft dough stage, oats produce less aftermath than barley.)

If oats are grown alone, seed at $110 \mathrm{~kg} / \mathrm{ha}(100 \mathrm{lb} / \mathrm{ac})$ using Random, Glen, Eagle, Fraser, Sioux, Rodney, or Garry. Victory is a late-maturing variety susceptible to rust and smuts.

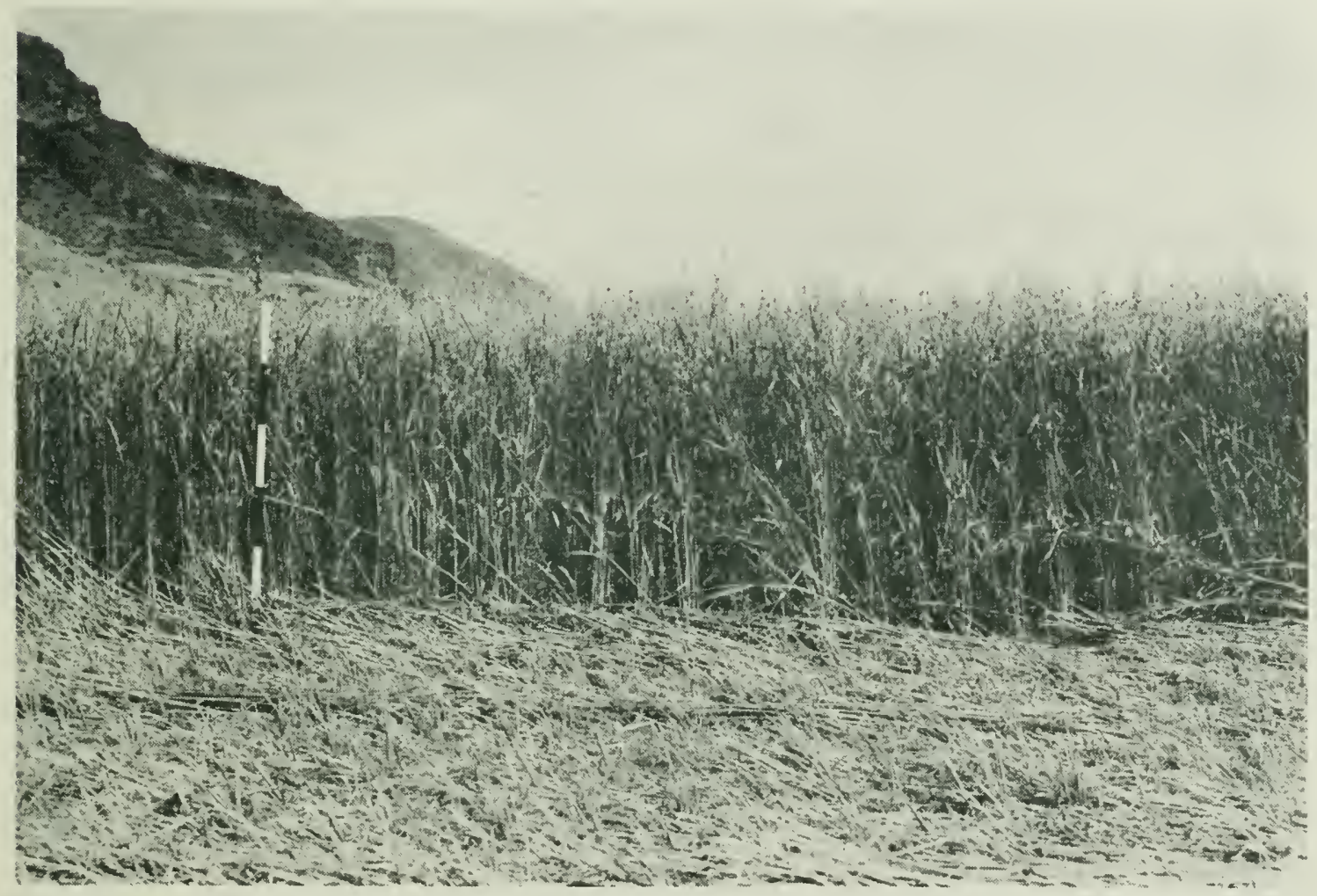

A good crop of oats, grown as a companion crop with alfalfa. 
Oats can be grazed 4-5 weeks after planting. Oats and fall rye are sometimes used as spring pasture. Seed oats at $80 \mathrm{~kg} / \mathrm{ha}(70 \mathrm{lb} / \mathrm{ac})$ and rye at $55 \mathrm{~kg} / \mathrm{ha}(50 \mathrm{lb} / \mathrm{ac})$ in the spring. After you cut the hay, the aftermath can be pastured until late fall.

Seeding oats at $80 \mathrm{~kg} / \mathrm{ha}(70 \mathrm{lb} / \mathrm{ac})$ and peas at $45 \mathrm{~kg} / \mathrm{ha}(40 \mathrm{lb} / \mathrm{ac})$ yields about 22 $\mathrm{t} /$ ha $(10 \mathrm{tons} / \mathrm{ac})$ of palatable silage or $7 \mathrm{t} / \mathrm{ha}(3 \mathrm{tons} / \mathrm{ac})$ of hay. The crop is ready when the oats are in the dough stage and the peas have started to pod. Austrian winter peas are normally used.

Oat hay or silage from a frosted crop or a crop grown under droughty conditions may contain deadly nitrates. Pigweed also readily accumulates nitrates and could prove toxic if present in oat hay or silage in quantity. If in doubt, have the crop analyzed for nitrates.

Of the small grain crops, barley is the most responsive to good management. It is potentially the highest yielding cereal for southern British Columbia and is an excellent silage crop. Galt and Jubilee are two high-yielding feed varieties. In the northern part of central British Columbia, $110 \mathrm{~kg} / \mathrm{ha}(100 \mathrm{lb} / \mathrm{ac}$ ) Jubilee barley or a mixture of $70 \mathrm{~kg} / \mathrm{ha}(60 \mathrm{lb} / \mathrm{ac})$ Jubilee barley and $45 \mathrm{~kg} / \mathrm{ha}(40 \mathrm{lb} / \mathrm{ac})$ Glen oats outyielded other varieties of barley, oats, spring wheat, and triticale.

Peas and barley may be a better combination than peas and oats. Barley is more digestible and higher in protein than oats. (In the Prince George area, peas fail to germinate under dry conditions.)

Fall rye is sometimes grown for spring pasture. Seed by the first week in September to ensure that plants are well established by freeze-up. Use the variety Sangaste or Petkus. If better winter hardiness is desirable, use Antelope or Frontier. Sangaste is the tallest of these varieties.

\section{SUDAN GRASS AND SWEET SUDAN}

Sudan grass is a summer annual that can be used for midsummer pasture, chopped greenfeed, silage, or hay. The pasture is usually better than the hay. Under irrigated conditions at the Research Station, Kamloops, Sudan grass yielded 5.5-7 tonnes of dry matter per hectare $(2.5-3$ tons/ac).

Before seeding Sudan grass, prepare a firm, moist, and finely granular seedbed. Use the variety Piper if the seed can be obtained. Sweet Sudan is more palatable to livestock but may contain more hydrocyanic acid. Seed $40 \mathrm{~kg} / \mathrm{ha}(35 \mathrm{lb} / \mathrm{ac}$ ) on irrigated land with a grain drill. As with all grasses, apply 340-0-S fertilizer at $225-340 \mathrm{~kg} / \mathrm{ha}(200-300 \mathrm{lb} / \mathrm{ac})$ and $11-48-0$ at $110 \mathrm{~kg} / \mathrm{ha}(100 \mathrm{lb} / \mathrm{ac})$.

If Sudan grass is used for pasture, divide the field into paddocks with electric fences for rotational grazing so that each section has about 4 weeks between grazings. If Sudan grass or the hybrid sorghums are used for grazing, be alert to the potential danger of hydrocyanic (prussic) acid poisoning. Sudan grass should not be pastured until it is $35-45 \mathrm{~cm}(14-18 \mathrm{in}$.) high. Frost may cause a buildup of prussic acid. If 
annuals are used for winter feed, there is not much danger because prussic acid in cured forage gradually disappears.

\section{PEARL MILLET}

The variety of millet most commonly used is Starr, but Empire is preferred as an annual hay. Pearl millet is used for temporary summer pasture because it produces hay and silage of rather inferior quality. Seed with a grain drill, using $17-28 \mathrm{~kg} / \mathrm{ha}$ $(15-25 \mathrm{lb} / \mathrm{ac})$. Millet may be seeded as late as July 15 if moisture conditions are favorable.

Compared with Sudan grass, pearl millet is coarser, is slightly less palatable to livestock, produces forage of slightly lower quality, and is less tolerant of severe drought. Pearl millet, like Sudan grass, should not be grazed until it is $45-55 \mathrm{~cm}$ (18-22 in.) high. Graze the field in four rotations that allow the plants to regrow to $50 \mathrm{~cm}$ (20 in.) before being grazed again. After each grazing, apply 34-0-0-S fertilizer at $100-135 \mathrm{~kg} / \mathrm{ha}(90-120 \mathrm{lb} / \mathrm{ac})$.

\section{SORGHUM AND HYBRID SORGHUM}

The main advantage of the sorghums over corn is that they are more drought tolerant. The new hybrid sorghums that outyield the old varieties have created a renewed interest in this forage crop. Even the new varieties, however, give only $75 \%$ the yield and $85 \%$ the food value of corn.

The best results at the Research Station, Kamloops, were in a weed-free seedbed seeded at $3.5-4.5 \mathrm{~kg} / \mathrm{ha}(3-4 \mathrm{lb} / \mathrm{ac})$ in $91-\mathrm{cm}(36-\mathrm{in}$.$) rows, and fertilized the$ same as corn. Harvest the crop before the first frost, although it only reaches the soft-dough stage, even if planted early.

You can plant sorghum later than corn and in about 8 weeks it is ready to graze.

\section{FODDER RAPE}

Rape makes an excellent late fall pasture for beef cattle, but can cause bloat. Dry feed should therefore be available to grazing cattle. For pasture, seed lightly at 1.7 $\mathrm{kg} / \mathrm{ha}(1.5 \mathrm{lb} / \mathrm{ac})$ in $71-\mathrm{cm}(28-\mathrm{in}$.) rows in early July. The crop is more efficiently used when grown in rows rather than broadcast.

\section{MARROWSTEM KALE}

This crop, in contrast with rape, is good fall pasture for dairy cattle. It does not cause off-flavors in milk.

As with rape, avoid heavy seedings. Seed $71-\mathrm{cm}(28-\mathrm{in}$.) rows at $2.25 \mathrm{~kg} / \mathrm{ha}$ (2 $\mathrm{lb} / \mathrm{ac})$. If it is to be used as fall pasture, sow no later than June 1. Apply fertilizer rich in $N, P$, and $K$. 


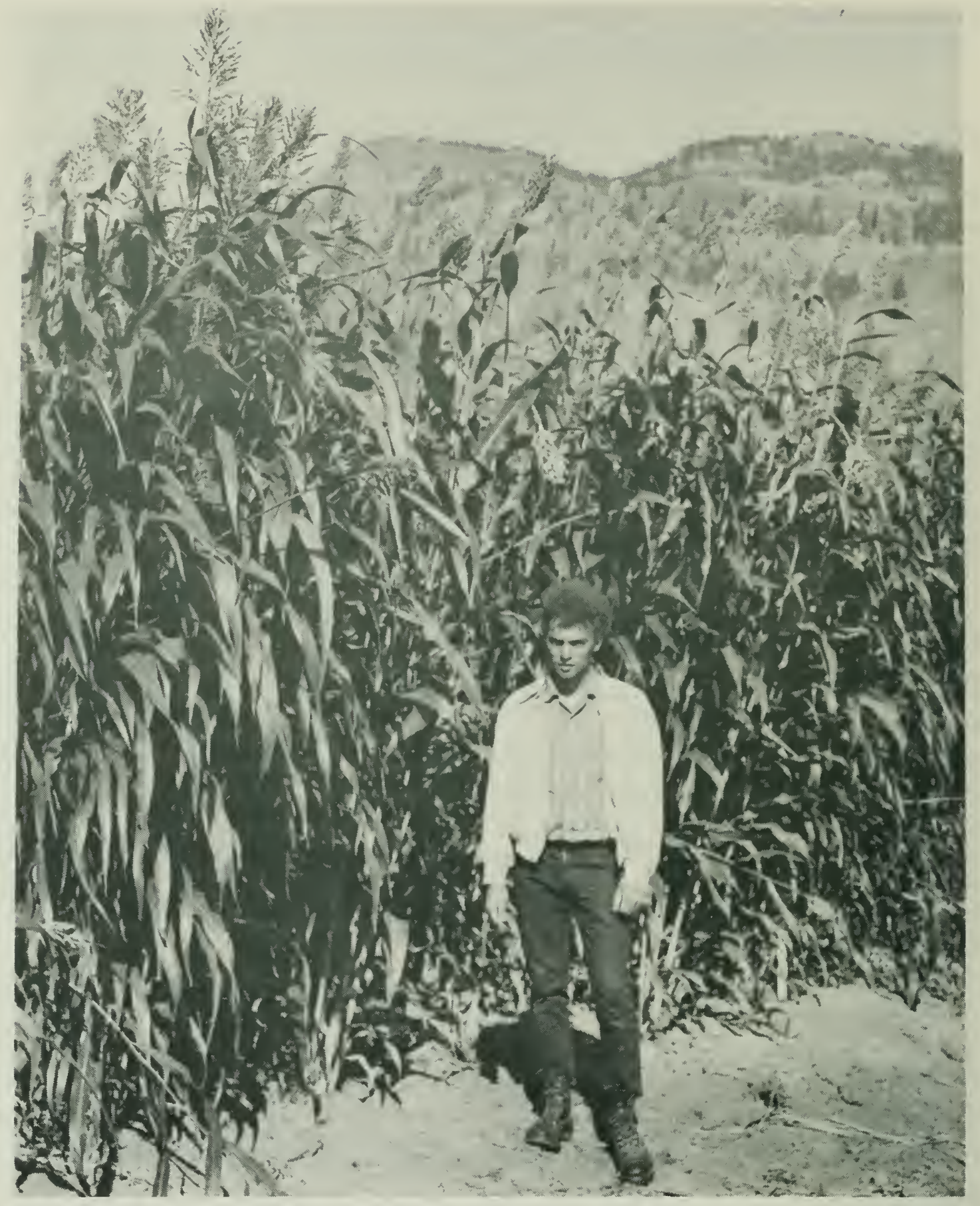

An excellent stand of hybrid sorghum.

\section{COMPARATIVE YIELDS OF ANNUAL CROPS}

Table 4 compares the amount of total digestible nutrients (TDN) produced by several forage crops but does not consider cost. Irrigated pasture may be the most economical source of TDN. 
TABLE 4. APPROXIMATE YIELD OF TOTAL DIGESTIBLE NUTRIENTS (TDN) AND ENERGY CONTENT (Mcal) FOR VARIOUS CROPS

\begin{tabular}{|c|c|c|c|c|}
\hline \multirow[b]{2}{*}{ Crop } & \multirow[b]{2}{*}{$\begin{array}{c}\text { Dry matter } \\
\text { t/ha } \\
\text { (tons/ac) }\end{array}$} & \multirow[b]{2}{*}{$\begin{array}{c}T^{T D N^{*}} \\
\text { t/ha } \\
\text { (tons/ac) }\end{array}$} & \multicolumn{2}{|c|}{ On a moisture-free basis } \\
\hline & & & $\begin{array}{c}\text { TDN } \\
\mathrm{kg} / 100 \mathrm{~kg} \\
(\mathrm{lb} / 100 \mathrm{lb})\end{array}$ & $\begin{array}{c}\text { Est. digestible } \\
\text { energy } \\
\text { Mcal per } \\
100 \mathrm{~kg} \\
(100 \mathrm{lb})\end{array}$ \\
\hline Corn silage & $\begin{array}{c}18 \\
(8.00)\end{array}$ & $\begin{array}{l}12.6 \\
(5.6)\end{array}$ & 68 & $\begin{array}{c}309 \\
(140)\end{array}$ \\
\hline Oat hay & $\begin{array}{l}7.85 \\
(3.5)\end{array}$ & $\begin{array}{l}4.76 \\
(2.1)\end{array}$ & 61 & $\begin{array}{c}269 \\
(122)\end{array}$ \\
\hline Alfalfa hay & $\begin{array}{c}13.5 \\
(6.00)\end{array}$ & $\begin{array}{c}7.56 \\
(3.36)\end{array}$ & 56 & $\begin{array}{c}247 \\
(112)\end{array}$ \\
\hline Oat-pea silage & $\begin{array}{c}10.1 \\
(4.50)\end{array}$ & $\begin{array}{c}6.48 \\
(2.88)\end{array}$ & 64 & $\begin{array}{c}282 \\
(128)\end{array}$ \\
\hline Pasture & $\begin{array}{c}9 \\
(4.00)\end{array}$ & $\begin{array}{c}6.30 \\
(2.80)\end{array}$ & 70 & $\begin{array}{c}309 \\
(140)\end{array}$ \\
\hline
\end{tabular}

* Figures were calculated from F. B. Morrison's Feeds and Feeding, 22nd Edition, The Morrison Publishing Co., Ithaca, N.Y., 1956. 


\section{CONVERSION FACTORS FOR METRIC SYSTEM}

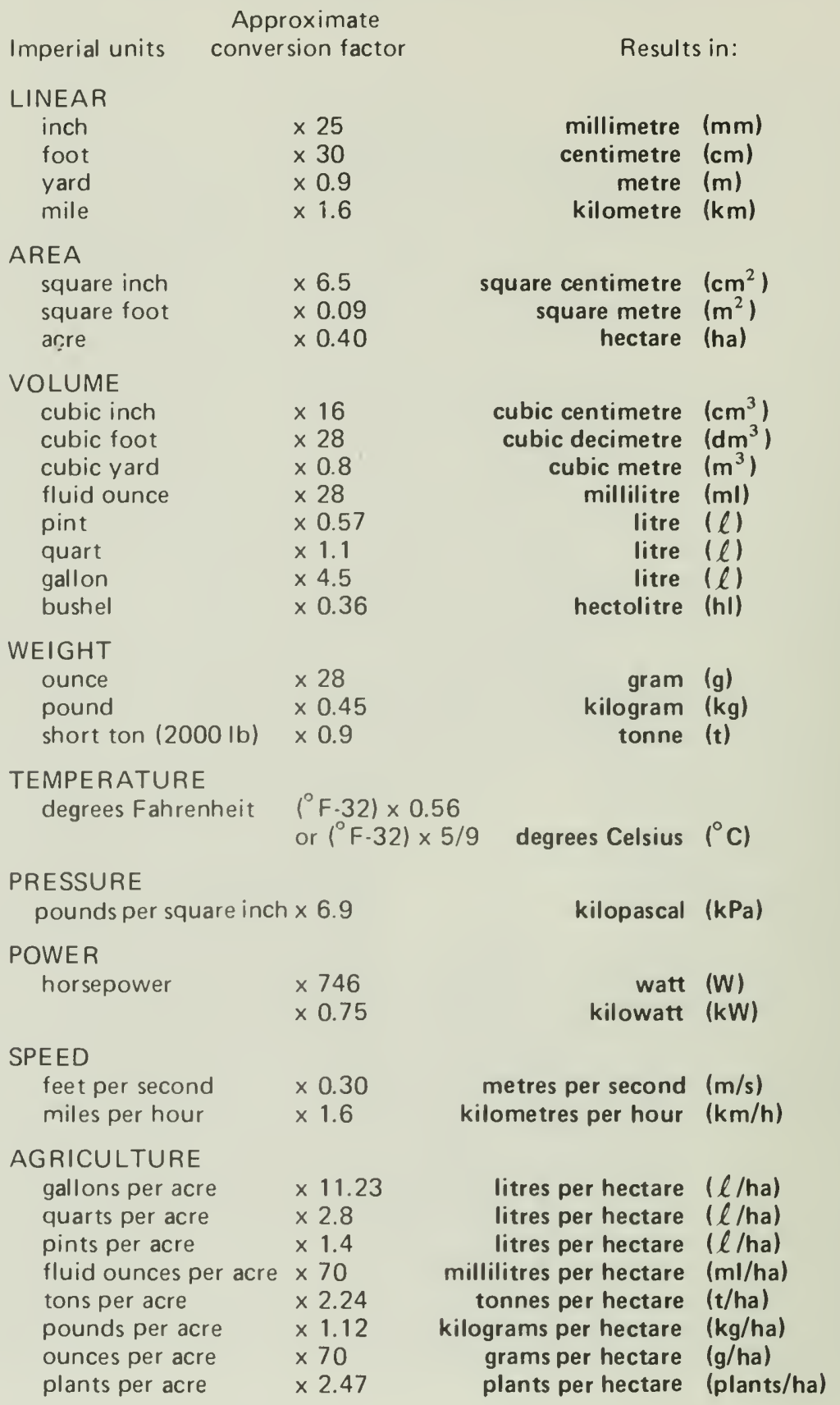





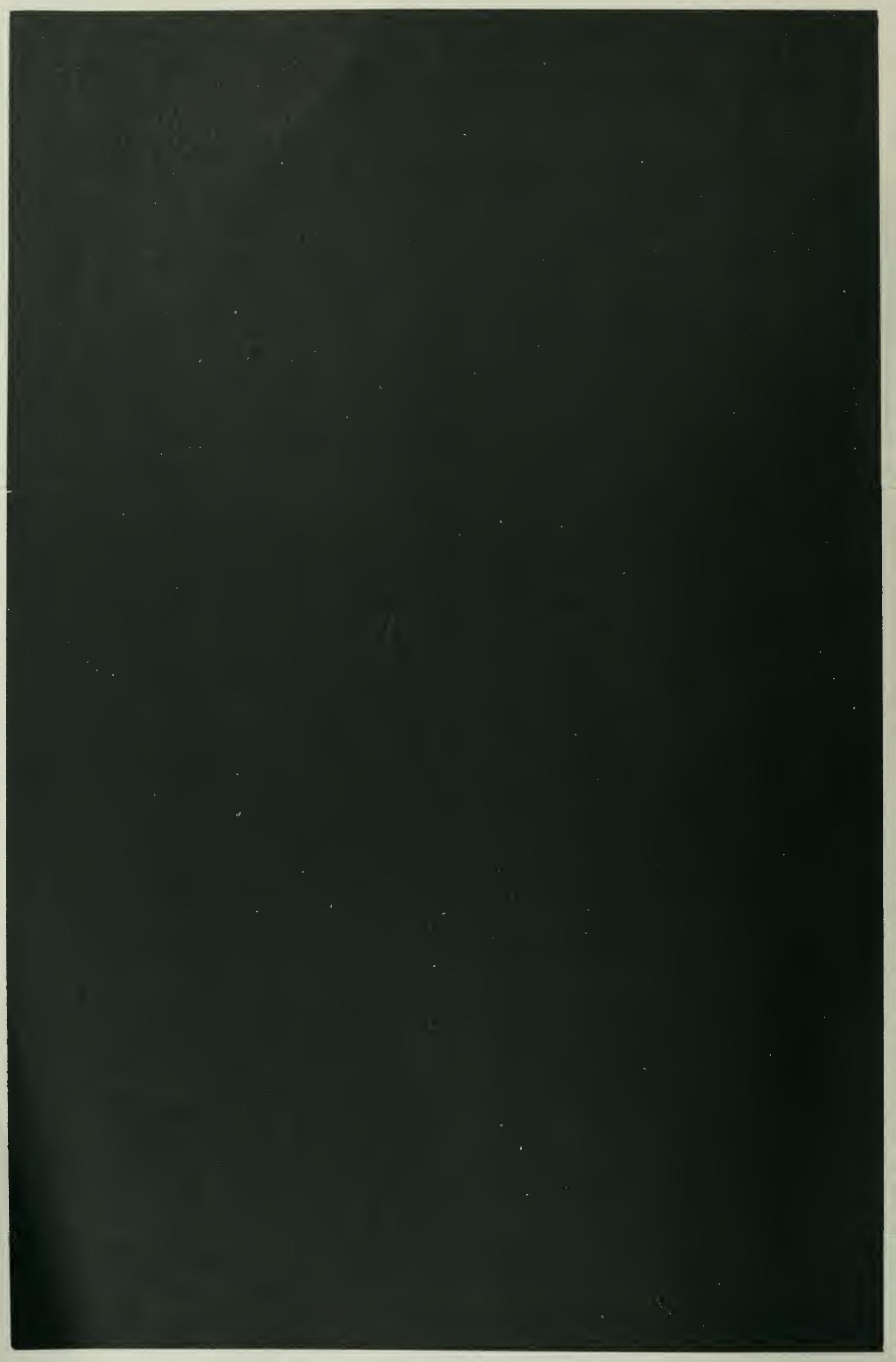

